\title{
DEVELOPING ENGLISH LESSON PLANS FOR THE FIRST YEAR STUDENTS OF SMA 18 MAKASSAR BASED ON THE 2013 CURRICULUM
}

\author{
Djuwairiah Ahmad \\ English Education Department \\ Husnul Khatimah Nur \\ English Education Department \\ hkhatimahnur@gmail.com
}

\begin{abstract}
This research developed English lesson plan based on 2013 curriculum for the first year students of SMAN 18 Makassar. The objective of this research was to develop English lesson plans based on the 2013 curriculum. It was conducted at the first year students of SMAN 18 Makassar. The significance of this research was for students and teacher. For students, the product of this research made the students more active in the teaching learning process. Then, for the teacher was helped them to make or design good lesson plans based on the 2013 curriculum. The research design of this research was Research \& Development (R\&D). It applied model R\&D which adapted from Borg \& Gall model. The steps of the model were research and information collecting, planning, developing preliminary form of product, main product revision, final product revision, and dissemination and implementation. The types of data of this research were qualitative and quantitative data. The research instruments were expert validation sheet and teacher feedback sheet to obtain the data about the product. The result of the research showed that the product was valid to implement in the classroom. It can be seen that the product valid from score that expert and teacher gave. The validation score that the researcher got was $\mathbf{8 0} \%$ meant the product was very good and score from teacher feedback was $\mathbf{9 5 \%}$. Based on the data above, the researcher concluded that developing English lesson plans based on 2013 curriculum that the researcher conducted was very good with the score on $\mathbf{8 0} \% \mathbf{- 9 5 \%}$.
\end{abstract}

KEYWORDS : English lesson plans, the 2013 curriculum, R\&D research.

\section{A. INTRODUCTION}

he idea of this study came from researchers' experience. When she taught on August 28 $8^{\text {th }}, 2014$ at SMPN 1 Bontonompo Gowa, an English teacher gave her an example of lesson plan that teacher used when teaching in her class. After researcher saw and analyzed the lesson plan, she found inapplicable components on the lesson plan that could not be used in the class. There were three inapplicable components on the lesson plan. First, indicators did 
not cover the aims of competence on syllabus. Second, every activity on the lesson plan did not cover the objective of the 2013 curriculum. Last, the learning activities on the lesson plan were not various. As the result, it made students not active in every learning activity.

Based on experience stated previously, the researcher tried to conduct a preliminary study on different school. She tried to analyze an English lesson plan that teacher used on SMAN 18 Makassar. She conducted a preliminary study dealing with the lesson plans used at the school on the last October 2013 at SMAN 18 Makassar about English lesson plan. She chose this school because it was easier for the researcher to develop the lesson plan because the teacher in this school was really cooperative. After analyzing the lesson plans, she still found inapplicable components as she found on SMPN 1 Bontonompo. In this preliminary study, she analyzed the components of a good English lesson plan. There were some components should be covered in English lesson plans. Those are; 1) competences used to make indicators on lesson plan; 2) learning objective; 3) learning materials; 4) learning method; 5) media; and 6) learning process based on 2013 curriculum. The aim of the preliminary study was to know whether the English lesson plans used on the school cover the components based on 2013 curriculum or not.

The researcher found on her preliminary study that English lesson plans used on SMAN 18 Makassar did not cover the components of lesson plan on 2013 curriculum. Moreover, the teacher did not know how to develop English lesson plans based on 2013 curriculum. As the result, the English lesson plans that teacher used on the school was still like lesson plan on KTSP curriculum.

After identified the problems and analyzed the factors, the researcher had a view that the existing problems above should be overcome. One way to overcome inapplicable components on English lesson plan on 2013 curriculum is to design good lesson plan based on 2013 curriculum. There are some rules to design a lesson plan. In this case, Mulyasa (2007) states that lesson plan is the learning scenario that being teacher's handout to prepare, to do, and to evaluate the result of learning. In the other hand, Permendikbud No. 81A (2013) states that lesson plan is learning plan developed in detail from main material or main topic based on syllabus. Lesson plans cover; (1) school data, subject, and class/ semester, (2) material, (3) time, (4) learning objective, basic competence, and indicator, (5) learning material, learning method, (6) media, instrument, (7) learning process, and (8) evaluation. The lesson plan on 2013 curriculum must cover the components.

Moreover, the research problem of this research was "how to develop english lesson plans for the first year students of SMAN 18 Makassar based on the 2013 
curriculum". Then, the research objective of this research was to develop English lesson plans for the first year students of SMAN 18 Makassar based on the 2013 curriculum. In addition, this research was beneficial both for students and teachers. For students, the product of this research made the students active in the teaching learning process. Then, for the teachers; the product of this research helped them to make or to design good lesson plans based on 2013 curriculum.

\section{B. LITERATURE REVIEW}

There were many previous findings that related with this research. First, Heryanto (2012) conducted a research about improving students ability in developing lesson plans. He found that the implementation of bloom's taxonomy dealing with cognitive domain learning stages model was an effective and efficient strategy in training the students to develop the lesson plan. The strategy implementation also supports more cooperative learning situation since the students work together to analayze and evaluate the lesson plan and syllabus. Second, Mutmainnah (2012) conducted a research about developing lesson plans and worksheet with contextual teaching learning. The result of this research was quality of lesson plans and worksheet that was very good. The characteristics of lesson plans and worksheet used contextual teaching learning. The result of this research found that using lesson plans and worksheet made students more active in learning process. Third, Dewi (2013) conducted a research about developing biology learning device oriented developing students compound intelligent. Result of this study was learning device oriented developing students compound intelligent that was suitable to use for students in learning process in the class.

\section{The 2013 curriculum}

The 2013 curriculum is a new curriculum that implemented in 2013/2014. This curriculum is the development of a curriculum that has been there before, both curriculum competency-based that has been initiated in 2004 and curriculum unit level 2006 (Fadillah: 2013). However, the pressure point on 2013 curriculum is an increase and balance of soft skills and hard skills that include some aspects such as attitudes competence, skills and knowledge. Then, re-position the competence derived from subjects turned into subjects that developed into competence. In addition, it is more of a integrative thematic learning in all of subjects. Thus, it is understood that 2013 curriculum is a curriculum developed to improve soft skills and hard skills. 
In this context, the 2013 curriculum seeks to further instill the values that are reflected in attitudes can be directly proportional to the students skills. In other words, between the soft skills and hard skills can be embedded in a balanced way, side by side, and can be applied in everyday life. With the 2013 curriculum, it is expected that learners can have the attitudes competence, skills, and knowledge that improved and developed in accordance with the level of education that has taken.

Regarding the purpose and function of the 2013 curriculum is mentioned that the function of curriculum is to develop the ability and character development as well as in the development of civilization dignified national life (Kemendikbud No 20: 2013). The purpose of 2013 curriculum is to develop the potential of students to become a man who is faith and fear to the God almighty one, noble, healthy, knowledgeable, skilled, creative, independent, and become democratic citizens and responsible.

There are four purposes of the 2013 curriculum (Fadillah: 2013). First, it improves the quality of education by balancing the hard skills and soft skills through the ability of attitudes, skills, and knowledge in order to face the global challenges that is always growing. Second, it establishes and improves human resources that are productive, creative, and innovative as the capital development of Indonesian and nation. Third, it relieves educators in presenting the material and prepares the teaching administration, because the government has prepared all components of the curriculum with textbooks used in learning. Fourth, it increases the participation of central and local governments and citizens in determining and controlling the quality of the implementation of KTSP Curriculum.

\section{Lesson Plans}

Planning ahead to identify a course of action that can effectively reach goals and objectives is an important first step in any process, and education is no exception (Barroso: 2005). In education, the planning tool is the lesson plan, which is a detailed description of an instructor's course of instruction for an individual lesson intended to help learners achieve a particular learning objective. Lesson plans communicate to learners what they will learn and how they will be assessed, and they help instructors organize content, materials, time, in-structional strategies, and assistance in the classroom.

Lesson planis a plan that draws the procedure and organizes the learning process to reach one of the standard competence in syllabus (Ikhwan: 2012) .In this case, attackingeducatorshavewatchedcarefully, goodmaterials, assessment, time allocation, 
learning resources andteaching methods thatwillbe usedso thatthe detailsof learning activitieshave been arrangedneatlyin planningthe implementation of learning.

\section{RESEARCH METHOD}

This research was Research and Development $(R \& D)$. R\&D can be defined as the research method that is in a intentional manner, systematical, finding, formulating, repairing, developing, producing, examining the product, model, method, procedure that is more excellent, new, effective, efficient, and productive (Putra: 2012). R\&D has many models which can be applied by researchers such as Sugiyono's model, ADDIE model Borg \& Gall's model, Dick and Carey's model, Kemp's model and many others. Based on many models stated previously, the researcher applied Borg \& Gall's model because it was more applicable because the model has more than one revision in the R\&D cycle. It made the product more valid.

Borg \& Gall (1983: 775) states the steps of this model, such as "research and information collecting, planning, develop preliminary form of product, preliminary field testing, main product revision, main field testing, operational product revision, operational field testing, final product revision, and dissemination and implementation". However, in this research the researcher did not apply all of steps R\&D from Borg and Gall. She only did research and information collecting, planning, developing preliminary form of product, main product revision, final product revision, and dissemination and implementation. Because the product which was developed only need to validate by the expert, before the product implement. The following figure presents the cycle of R\&D adapted from Borg \& Gall (1983:775).

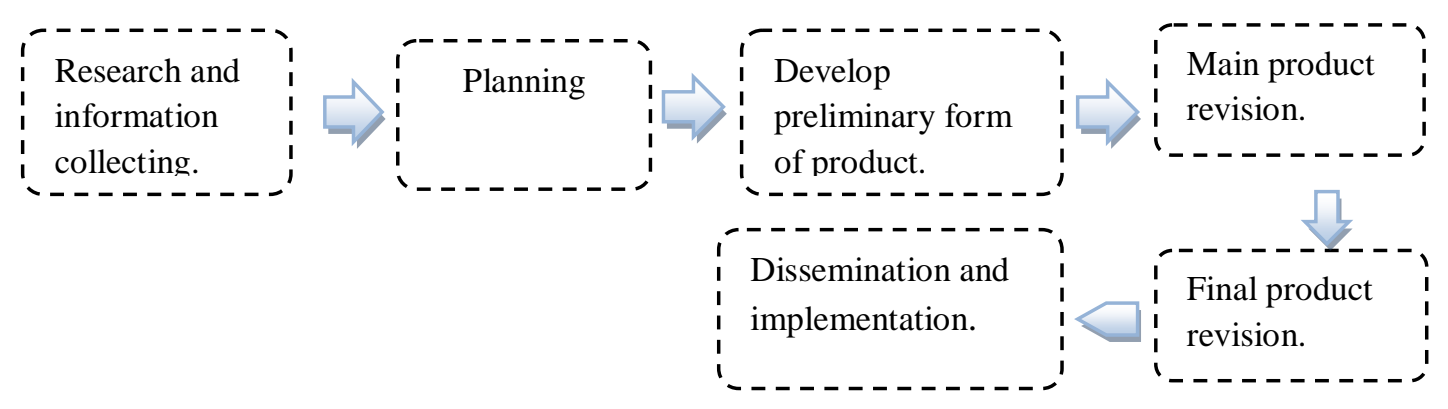

Figure 1 Cycle of R\&D adapted from Borg \& Gall (Borg \& Gall :1983)

Based on the figure above that is adapted from Borg and Gall model, the researcher explains all of steps on the figure as follows; First, Research and information collecting; in this step, the researcher did a study literature to collect 
information about the problem. Then, the researcher prepared the design of product. Second, Planning; after collecting information about the research, the researcher determined the aim in every step of the cycle of the research. Third, Develop primary form of product; this step, the researcher developed design of the product. Then, she designed product. Fourth, Main product revision; after preliminary study has done, the researcher revises about first product which is produced based on the result of the first try-out. This revision can be done more than one time, until the researcher gets a product which can be tried-out in a big scale. Fifth, Final product revision; in this step, the researcher did a final revision to get a final product which is readied to implement in a class. Sixth, Dissemination and implementation; after the researcher has gotten a final product, the product is ready to implement in a class.

\section{FINDINGS AND DISCUSSION}

\section{Finding}

The result of the research finished based on steps of $R \& D$ which had been done on the developing. There were six steps that had been done to get a good product. The data about English lesson plans based on the 2013 curriculum had been analyzed. The steps were;

\section{a. Research and Information Collecting}

Research and information collecting covered; 1) need analysis, and 2) Study literature.

\section{1) Need Analysis}

Products developed were English lesson plan. The products were the educational product that is needed in learning process. The product was from preliminary study that researcher did in the school. She found that the teacher did not know how to design English lesson plan based on the 2013 curriculum based on the lesson plans that teacher gave to the researcher. It made the researcher conducted this research.

\section{2) Study Literature}

Developing an English lesson plan was needed to do study literature. This study was to find the concept and theoretical foundation which made a good product. the concept of the product that researcher found in the study literature are about the 2013 curriculum, the elements changes of the 2013 curriculum, structure of 
the 2013 curriculum, lesson plans in the 2013 curriculum, the principle of lesson plans development, the scope of lesson plans, the component of lesson plan, the steps of developing lesson plan, the form of lesson plan, and concept and strategy assessment in the lesson plan. Based on the result of this study, it was to know the procedures and outcomes of research, and also knew the difficulties and obstacles which were faced in this research. The example of lesson plan based on the 2013 curriculum can be seen in Appendix 4.

\section{b. Planning}

The researcher planned the component of lesson plans being developed based on the 2013 curriculum. The product design that was developed covering: a) learning identity; b) learning indicators; c) learning objectives; d) learning material; e) learning sources; f) learning media; g) learning method; h) learning scenario; and i) assessment.

\section{c. Develop Preliminary Form of Product}

The results of need analysis were the information about the characteristics of product developed. Then, the product was still a draft which was rudimentary. Although, this was a draft, the product had been arranged completely. The component consist of core competence, basic competence, learning indicator, learning objective, learning material, learning method, media, learning scenario, and assessment. First, core competence and basic competence of the product were added from the syllabus of the 2013 curriculum. Second, learning indicator in the product was developed from the basic competence. Third, learning objective was same with the learning indicator which was developed based on the basic competence. Fourth, learning material was developed based on the students need and the material that had given in the syllabus. Fifth, learning method and media were developed based on the syllabus. Sixth, learning scenario that was developed on the lesson plan was divided based on the time allotment. Last, assessment that was in the lesson plan had indicator in every competence of assessment.

\section{d. Main Product Revision}

The product that was developed had been revised by the researcher from the expert comment. There was four times product revision. The researcher obtained the 
expert comment about the product. It used to produce a good product. Some comments are;

Table 4.Expert Comment

\begin{tabular}{|c|c|}
\hline Components & Expert Comment \\
\hline $\begin{array}{l}\text { Learning Identity: Educational unit, class, } \\
\text { semester, program, subject, the number of } \\
\text { meetings. }\end{array}$ & $\begin{array}{l}\text { The learning identity has not program. It } \\
\text { needed to add the program. }\end{array}$ \\
\hline $\begin{array}{l}\text { Learning Material: } \\
\text { The appropriateness with learning objective. } \\
\text { The appropriateness with characteristics of } \\
\text { students. } \\
\text { The steps of learning material. }\end{array}$ & $\begin{array}{l}\text { The learning material was not complete } \\
\text { based on the learning objective. }\end{array}$ \\
\hline $\begin{array}{l}\text { Assessment: } \\
\text { The appropriateness of form, technique and } \\
\text { instrument with indicators. } \\
\text { The appropriateness of form, technique and } \\
\text { instrument with cognitive evaluation. } \\
\text { The appropriateness of form, technique and } \\
\text { instrument with psychomotor evaluation. }\end{array}$ & $\begin{array}{l}\text { Indicators of assessment needed to } \\
\text { repair. }\end{array}$ \\
\hline
\end{tabular}

\section{Final Product Revision}

The aim of final product revision was to determine whether the product was ready to use. This step was done to finish the product. The final product revision did from the expert comment that the researcher obtained to validate the product. It was valid based on the result of validation from the expert. He gave score on every question on the validation sheet. The researcher found that the product was valid to apply as the lesson plan based on the 2013 curriculum from the score that researcher obtained in the expert validation sheet and teacher feedback sheet (Table 5 and Table 6). The result of the developing product showed from the score of validation sheet as follows;

Table 5.Score from validation sheet (see Appendix 1)

\begin{tabular}{lll}
\hline No. & Component of Lesson Plan & Score \\
\hline 1. & 1.A & 2 \\
2. & $1 . \mathrm{B}$ & 3 \\
3. & $2 . \mathrm{B}$ & 3 \\
\hline
\end{tabular}




\begin{tabular}{|c|c|c|}
\hline 4. & $3 . \mathrm{B}$ & 3 \\
\hline 5. & $4 . \mathrm{B}$ & 3 \\
\hline 6. & $1 . C$ & 3 \\
\hline 7. & 2.C & 3 \\
\hline 8. & 1.D & 2 \\
\hline 9. & 2.D & 3 \\
\hline 10. & 3.D & 1 \\
\hline 11. & 1.E & 3 \\
\hline 12. & 2.E & 3 \\
\hline 13. & 3.E & \\
\hline 14. & 4.E & 3 \\
\hline 15. & $1 . \mathrm{F}$ & 3 \\
\hline 16. & $2 . \mathrm{F}$ & 3 \\
\hline 17. & 3.F & 3 \\
\hline 18. & 4.F & 3 \\
\hline 19. & $1 . G$ & 3 \\
\hline 20. & $2 . G$ & 3 \\
\hline 21. & $3 . G$ & 3 \\
\hline 22. & 1.H & 3 \\
\hline 23. & 2.H & 3 \\
\hline 24. & $3 . \mathrm{H}$ & 3 \\
\hline 25. & 4.H & 3 \\
\hline 26. & $5 . \mathrm{H}$ & 3 \\
\hline 27. & 1.I & 2 \\
\hline 28. & 2.I & 3 \\
\hline 29. & 3.I & 2 \\
\hline 30. & 4.I & 2 \\
\hline Score & & 81 \\
\hline
\end{tabular}

The score that the researcher obtained from the validation sheet from expert is $90 \%$. It meant that the product is very good to implement in the class as English lesson plan based on the 2013 curriculum.

Based on the table of validation above, the product that developed was valid based on the criteria of validation (Kemendikbud: 2013). Criteria of validation showed that if score was in $75 \%-100 \%$ meant that product was very good, and the result of total score from the expert validation was in $75 \%-100 \%$. Although, there 
was some aspects which was not in the high score, but another aspect obtained high score to make this product very good to implement in the school as the example of English lesson plan based on 2013 curriculum.

\section{Dissemination and Implementation}

The product which had been developed was ready to implement in school. Especially, the first year students of SMAN 18 Makassar that used the English lesson plan based on 2013 curriculum was in the school.

The product has been analyzed by the English teacher who taught in the first year students. The score that the researcher obtained from feedback that was given by teacher as follows;

Table 6. Feedback about the product from teacher

\begin{tabular}{|c|c|c|}
\hline No & Component of Lesson Plan & Score \\
\hline 1. & $1 . \mathrm{A}$ & 3 \\
\hline 2. & $1 . \mathrm{B}$ & 3 \\
\hline 3. & 2.B & 3 \\
\hline 4. & $3 . \mathrm{B}$ & 3 \\
\hline 5. & 4.B & 3 \\
\hline 6. & 1.C & 3 \\
\hline 7. & 2.C & 3 \\
\hline 8. & 1.D & 3 \\
\hline 9. & 2.D & 3 \\
\hline 10. & 3.D & 2 \\
\hline 11. & 1.E & 3 \\
\hline 12. & 2.E & 3 \\
\hline 13. & 3.E & 3 \\
\hline 14. & 4.E & 3 \\
\hline 15. & 1.F & 3 \\
\hline 16. & 2.F & 3 \\
\hline 17. & 3.F & 3 \\
\hline 18. & 4.F & 3 \\
\hline 19. & 1.G & 3 \\
\hline
\end{tabular}




\begin{tabular}{|c|c|c|}
\hline 20 & $2 . G$ & 3 \\
\hline 21. & $3 . G$ & 3 \\
\hline 22. & 1.H & 3 \\
\hline 23. & 2.H & 3 \\
\hline 24. & $3 . \mathrm{H}$ & 3 \\
\hline 25. & 4.H & 3 \\
\hline 26. & $5 . \mathrm{H}$ & 3 \\
\hline 27. & 1.I & 3 \\
\hline 28. & 2.I & 3 \\
\hline 29. & $3 . I$ & 3 \\
\hline 30. & 4.I & 2 \\
\hline Score & & 86 \\
\hline
\end{tabular}

The score of teacher feedback sheet given by the English teacher of SMAN 18 Makassar showed above. From the score, the teacher gave 95\% for the product. It meant that the teacher responded the product was very good $75 \%-100 \%$ based on the criteria validation (Kemendikbud: 2013).

\section{Discussion}

This part presents the result of the data analysis. The data was found on the validation sheet from expert and teacher feedback sheet. The researcher obtained the data and analyzed the data. The minimal criteria of a valid product were $70 \%$ (Kemendikbud: 2013).

Based on the sixth step had done by the researcher, namely: 1) Research and information collecting; 2) Planning; 3) Develop preliminary form of product; 4) Main product revision; 5) Final product revision; and 6) Dissemination and implementation. The researcher obtained a maximal score from the expert that was $90 \%$. It meant that the product valid to use in the school.

The sixth steps of developing the product explained more here. First, research and information collecting was the first step that the researcher did in this research. She did a study literature to obtain the criteria of a valid lesson plan based on the 2013 curriculum. It was the foundation to develop the product in a good way. Second, the researcher had done collecting the information in the study literature. Then she tried to plan the draft of the product. Third, she developed the first product based on the study literature that she had done. Fourth, she did revision 
from the expert comment about the product. The product that had been analyzed from the expert obtained a low score. Fifth, she had revised the product based on the expert comment. It made the result of the final revised that obtained a maximal score. The score of final revision was $90 \%$ from the expert (Table. 5). It meant that the product was ready to use. Finally, the product readied to implement in the school.

The product had been analyzed from the expert. Then, the researcher tried to ask the teacher feedback about the product that had been validated. She gave the teacher feedback sheet to the teacher and asked him to give the score about the product. it made the product more valid to use. The researcher obtained score from teacher feedback sheet that was 95\%. It meant that the score in the high score based on the kemendikbud.

The result of this research related with Mutmainnah's research (2012). She found that a good lesson plans and worksheet can be made the students more active in learning activity in the class. Then, this research was to make a good lesson plans based on the 2013 curriculum and it was validated by the expert before implemented in the class.

The product that was developed in this research had been fulfilled the form of a good lesson plan based on the 2013 curriculum (Table.1) which stated from Permendikbud 81A (2013). It was validated by the expert and the expert gave the comment about the product to develop the product (Table.4). It had been covered the principle of lesson plan according to Heinich (2001). He stated that the lesson plan should have ABCD aspect and the product had been covered the aspects. Then, it also had been covered the scope of the lesson plan based on the Permendikbud No. 81A (2013) which stated that lesson plan included: 1) data of school, subject and grade; 2) the subject matter; 3) time allocation; 4) learning objectives, standard competence and indicator; 5) learning material, learning method; 6) media; 7) learning activities; and 8) assessment. The product that was developed obtained a valid data based on the criteria of validation in permendikbud. 


\section{E. CONCLUSION AND RECOMMENDATION}

\section{Conclusion}

Based on the research findings and discussion in the previous chapter, the researcher comes to the following conclusions. The result of developing English lesson plan for the first year students of SMAN 18 Makassar based on the 2013 curriculum is very good. The finding indicates that the product can be implemented in the school as the example of a good English lesson plan based on 2013 curriculum. Because the product has all of components of a good English lesson plan based on 2013 curriculum, it was validated by the expert.

\section{Recommendation}

The result that was first, the lesson plan based on the 2013 curriculum should contain all components of a good lesson plan. The component are core competence, basic competence, learning indicators, learning objective, learning material, learning method, learning media, learning scenario, and assessment. Second, the English teacher should know how to develop every component of English lesson plan based on the 2013 curriculum. Because the content of every component in the 2013 curriculum is very different with the previous curriculum, the 2013 curriculum has many kinds of material for instance.

\section{REFERENCE}

Barroso, (2005). K., \&Pon, S. Effective Lesson Planning, A Facilitators Guide California Adult Literacy Professional Development Project.American Institutes for Research, Sacramento: CA.

Borg, W.R.\& Gall, M.D. (1983). Educational Research: An Introduction. New York: Longman.1983.

Brinkley, M., Erstad, O., Herman, J., et.al. (2010). Assesment and Teaching of $21^{\text {st }}$ Century Skill.Melbourne: The University of Melbourne Press.

Dewi.(2013). Pengembangan Perangkat Pembelajaran IPA Terpadu. Thesis.Yogyakarta. Universitas Negeri Yogyakarta.

Fadillah, M. ImplemetasiKurikulum 2013 dalamPembelajaran SD/MI, SMP/MTS, \& SMA/MA. Yogyakarta: Ar-Ruzz Media.2013.

Hamalik.KeunggulandanKekuranganPendidikanPadaKurikulum

RemajaRosdakarya. 2013.

2013.Bandung: 
Heryanto.MeningkatkanKemampuanMahasiswadalamMengembangkan RPP denganMenggunakan Taxonomy Bloom untukKelas $X$ Semester II.Thesis. Yogyakarta.UIN Kalijaga. 2012.

Heinich, R., Molenda, M., Russell, J., \&Smaldino, S. Instructional Media and Technologies for Learning. Engle Cliffs. ( th $^{\text {Edition}) . N j: ~ P r e n t i c e ~ H a l l . ~} 2001$.

Ikhwan, A. SilabusdanRpp (RencanaPelaksanaanPembelajaran) Tematik.Article. 2012.

Kurinasih, Imas. \& Sani, Berlin.ImplementasiKurikulum KonseperPenerapan.Surabaya: Kata Pen. 2014.

Lengkanawati, N. EFL Teachers" Competence in the Context of English Curriculum 2004: Implication for EFL Teacher Education. TEFLIN Journal.Vol 16 No. 1. 2005.

Mida, L. M. Kupas Tuntas Kurikulum 2013. Jakarta: Kata Pena. 2013.

Mulyasa.(2007).Standar Kompetensi dan Sertifikasi Guru. Bandung: Rosdakarya. 2007.

Mutmainnah.2012)Pengembangan Rpp dan Lks Ipa Terpadu Dengan Pendekatan Kontekstual (Contextual Teaching Learning) Pada Tema Hujan Asam Dan Pengarubnya Terbadap Lingkungan Untuk Meningkatkan Keaktifan Siswa Dalam Pembelajaran Ipa. Thesis.Yogyakarta.UniversitasNegeri Yogyakarta.

Peraturan Menteri Pendidikan dan Kebudayaan Republik Indonesia No 81A.Lampiran 4 Tentang Implementasi Kurikulum Pedoman Umum Pembelajaran. 2013.

Permendikbud No 104Tentang Model Rencana Pelaksanan Pembelajaran (RPP) kurikulum.2013.

Permendikbud No 65Tentang Standar Proses Pendidikan. 2013.

Permendiknas No. 22Tentang Standar Isi. 2006.

Permendikbud No. 70 Tentang Kerangka Dasar dan Struktur Kurikulum Kejuruan dan Sekolah Menengah Kejuruan. 2013.

Putra, K.A. (2012). Mengurangi Benang Kusut Pembelajaran Bahasa Inggris. Radar Lampung: 18 April 2012.

Putra, N.(2012) Research \& Development Penelitian dan Pengembangan: Suatu Pengantar.Jakarta: Fajarinter pratama Offset.

Setiadi, B. (2009) The Challenges of the Teaching of English in Indonesia. Paper Presented at Professership Inaguration at the University of Lampung: on August 20. 2009.

Sugiyono. (2008).MetodePenelitianPendidikan: PendekatanKuantitatif, Kualitatif, dan R\&D. Bandung: Alfabet.

Tim Pekerti-AA PPSP LPP. (2007).PanduanPengembanganKurikulum. Surakarta: LPPUSM. 